\title{
Chapter 9 \\ Changes in the Transfer of Fallout Radiocaesium from Pasture Harvested in Ibaraki Prefecture, Japan, to Cow Milk two Months After the Fukushima Daiichi Nuclear Power Plant Accident
}

\author{
Noboru Manabe, Tomotsugu Takahashi, Jun-You Li, Keitaro Tanoi, \\ and Tomoko M. Nakanishi
}

\begin{abstract}
Changes in the radioactivity of ${ }^{131} \mathrm{I},{ }^{134} \mathrm{Cs}$, and ${ }^{137} \mathrm{Cs}$ in milk produced by cows given pasture that was contaminated with these radioactive nuclides caused by the Fukushima Daiichi nuclear power plant accident on 11 March 2011, were examined between 16 May and 26 June 2011. Pasture (Italian ryegrass) was seeded on September 2010, and cultivated in the Animal Resource Science Center of the University of Tokyo (about $140 \mathrm{~km}$ south-west of the power plant). Pasture was harvested 2 months after the accident and prepared for fermented grass forage (haylage). The cows examined were born and kept in the Animal Resource Science Center and were given commercial mixed feed (total mixed ration forage: TMR) that contained no radioactive ${ }^{131} \mathrm{I},{ }^{134} \mathrm{Cs}$, or ${ }^{137} \mathrm{Cs}$, for 2 weeks before being examined. They were given haylage and TMR (10 and $25 \mathrm{~kg} / 600 \mathrm{~kg}$ of body weight/day, respectively) for 2 weeks, and then were given only TMR $(35 \mathrm{~kg} / 600 \mathrm{~kg}$ of body weight/day) for 2 weeks. During the examination, milk was collected twice a day and mixed in each cow. The weight and radioactivity of ${ }^{131} \mathrm{I},{ }^{134} \mathrm{Cs}$, and ${ }^{137} \mathrm{Cs}$ of the mixed milk in each cow were measured daily. No radioactive ${ }^{131} \mathrm{I}$ was detected in either the milk or haylage. The radioactivity of ${ }^{134} \mathrm{Cs}$ and ${ }^{137} \mathrm{Cs}$ contained in the mixed feed of haylage and TMR was $380 \mathrm{~Bq} / \mathrm{kg}$ (radiocesium radioactivity was represented as total concentrations of ${ }^{134} \mathrm{Cs}$ and ${ }^{137} \mathrm{Cs}$ ). Radiocesium radioactivity concentrations in the milk rapidly increased to $30 \mathrm{~Bq} / \mathrm{kg}$ after 4 days from the start of feeding and equilibrated to $36 \mathrm{~Bq} / \mathrm{kg}$ after 12 days. After that, cows were given TMR containing no radiocesium, and radioactivity concentrations of radiocesium in the milk rapidly decreased. Two weeks after stopping radiocesium feeding, radioactivity concentrations were less than $5 \mathrm{~Bq} / \mathrm{kg}$ (background level). In summary, when the
\end{abstract}

\footnotetext{
N. Manabe $(\varangle) \bullet$ T. Takahashi • J.-Y. Li

Animal Resource Science Center, Graduate School of Agricultural and Life Sciences,

The University of Tokyo, Kasama 319-0206, Japan

e-mail: amanabe@mail.ecc.u-tokyo.ac.jp

K. Tanoi • T.M. Nakanishi

Graduate School of Agricultural and Life Sciences,

The University of Tokyo, 1-1-1 Yayoi, Bunkyo-ku, Tokyo 113-8657, Japan
} 
cow (approximately $600 \mathrm{~kg}$ of body weight) was given feed with radioactive ${ }^{134} \mathrm{Cs}$ and ${ }^{137} \mathrm{Cs}\left(12,600 \mathrm{~Bq} / 600 \mathrm{~kg}\right.$ body weight/day), $5.71 \%$ of ${ }^{134} \mathrm{Cs}$ and ${ }^{137} \mathrm{Cs}$ was secreted into the milk ( $720 \mathrm{~Bq} / 20 \mathrm{~kg}$ milk/day). Radioactivity concentrations of radiocesium in the milk were lower than new standard $(50 \mathrm{~Bq} / \mathrm{kg}$ ) of Japan.

Keywords Cow milk $\bullet$ Fukushima Daiichi nuclear power plant accident $\bullet$ Pasture

- Radiocaesium

\subsection{Introduction}

On 11 March 2011, the declaration of a nuclear emergency situation was issued by the Japanese Prime Minister because of the Fukushima Daiichi nuclear power plant accident that resulted from the East Japan earthquake. On 17 March 2011, the Japanese Ministry of Health, Labour, and Welfare established a provisional regulation level for cow milk that was less than $70 \mathrm{~Bq} / \mathrm{kg}$ radioactive iodine and $200 \mathrm{~Bq} / \mathrm{kg}$ radiocesium $\left({ }^{134} \mathrm{Cs}\right.$ and $\left.{ }^{137} \mathrm{Cs}\right)$. On 1 April 2012, a more stringent new standard for milk of $50 \mathrm{~Bq} / \mathrm{kg}$ radiocesium was established. However, under livestock feeding management conditions in Japan, it has not been fully understood (1) how much radioactive nuclides transfer from the haylage to the milk, when dairy cows are given grass haylage prepared from pasture grown under nuclear power plant accident conditions, or (2) after that, whether radioactive nuclides rapidly disappear from the milk or not in cows are given forages without radioactive nuclides. In order to propose appropriate risk management related to the production of cow milk, which is an excellent food for infants and children who are considered to have high sensitivity to radiation, we performed the present study at the Animal Resource Science Center of The University of Tokyo (Kasama, Japan), which is located about $140 \mathrm{~km}$ south-west in a straight-line from the Fukushima Daiichi nuclear power plant.

\subsection{Experimental Procedure}

(a) Preparation of cow feed containing radioactive nuclides caused by the accident in the Fukushima Daiichi nuclear power plant: grass (Italian ryegrass, Lolium multiflorum Lam.) was seeded in October 2010, and cultivated in a field at the Animal Resource Science Center. After mowing between 10 and 15 May 2012 ( 2 months after the accident), raw grass $\left({ }^{131} \mathrm{I}\right.$ : not detectable level and ${ }^{134} \mathrm{Cs}$ and ${ }^{137} \mathrm{Cs}$ : 54 and $59 \mathrm{~Bq} / \mathrm{kg}$, respectively) was dried for several days, and then packed in plastic film to prepare anaerobically fermented grass forage (haylage). Haylage contained radioactive nuclides $\left({ }^{131} \mathrm{I}\right.$ : not detectable level. ${ }^{134} \mathrm{Cs}$ and ${ }^{137} \mathrm{Cs}: 600$ and $660 \mathrm{~Bq} / \mathrm{kg}$, respectively).

(b) Cow feed without radioactive nuclides caused by the nuclear power plant accident: commercial mixed feed (total mixed ration: TMR), which was purchased from Zen-Noh Feed (Tokyo, Japan), containing no detectable ${ }^{131} \mathrm{I},{ }^{134} \mathrm{Cs}$, or ${ }^{37} \mathrm{Cs}$ 
was used. TMR contains the required levels of nutrients (energy, protein, minerals, and vitamins) needed by the cow. The raw materials of TMR were as follows: $45 \%$ maize, $29 \%$ mixture of wheat bran and rice bran, $21 \%$ mixture of soybean oil cake and rapeseed oil cake, and 5\% additives (minerals and vitamins). Feed ingredients of TMR were as follows: $16 \%$ crude protein, $2.5 \%$ crude fat, $10 \%$ crude fibers, $10 \%$ crude ash, $0.8 \%$ calcium, and $0.5 \%$ phosphorus.

(c) Lactating dairy cows: lactating dairy cows born and kept in the Animal Resource Science Center were used. According to a notice by the Government of Japan (MAFF 2011), cows were raised in a closed cow barn after 20 April 2012, and were given TMR.

(d) Study design: cows were given TMR (35 kg/600 kg body weight/day) for 2 weeks before the examination (between 16 and 29 May 2011), then they were divided into two groups (control and test groups). In the control group, three cows $(636 \pm 34 \mathrm{~kg}$ body weight) were given TMR for 4 weeks. In the test group, three cows $(593 \pm 23 \mathrm{~kg}$ body weight) were given a mixture of haylage and TMR (10 and $25 \mathrm{~kg} / 600 \mathrm{~kg}$ of body weight/ day, respectively) for 2 weeks (between 30 May and 12 June 2011), and then were given only TMR for 2 weeks (between 13 and 26 June 2011). During the examination (from 30 May to 26 June 2011), cow milk was collected, weighed twice a day, and mixed in each cow. The radioactivity of ${ }^{131} \mathrm{I},{ }^{134} \mathrm{Cs}$, and ${ }^{137} \mathrm{Cs}$ of the mixed milk in each cow was measured daily. The body weight of each cow was measured on the 16 and 30 May, and 13 and 27 June 2011. During the study period, cows were allowed to freely drink water through automatic water supply equipment. Drinking water had no detectable radioactivity from ${ }^{131} \mathrm{I},{ }^{134} \mathrm{Cs}$, or ${ }^{137} \mathrm{Cs}$.

(e) Test items: during the experiment, a veterinarian diagnosed the health status of cows. On the 16 and 30 May, and 13 and 27 June 2011, blood and urine biochemical tests and haematological analyses using automatic analyzers were carried. Radioactive element concentrations in each milk sample were measured by a germanium semiconductor detector, and each nuclide was identified by gamma-ray spectrometry. ${ }^{134} \mathrm{Cs}$ and ${ }^{137} \mathrm{Cs}$ were quantified at 661.6 and $604.7 \mathrm{keV}$, respectively, and then each $\mathrm{Bq}$ value was calculated by the calibration of count value. Each radionuclide concentration was calculated based on the weight of each sample. The detection limit was set to three times the standard deviation of the background.

\subsection{Results}

(a) Body weight, feed intake, and milk yield: throughout the study period, there were no significant differences in body weight, feed intake, or milk yield (Fig. 9.1) between the two experimental groups.

(b) Health status: during the experiment, no remarkable symptoms were found in any cows from the two experimental groups. There were no significant differences in 


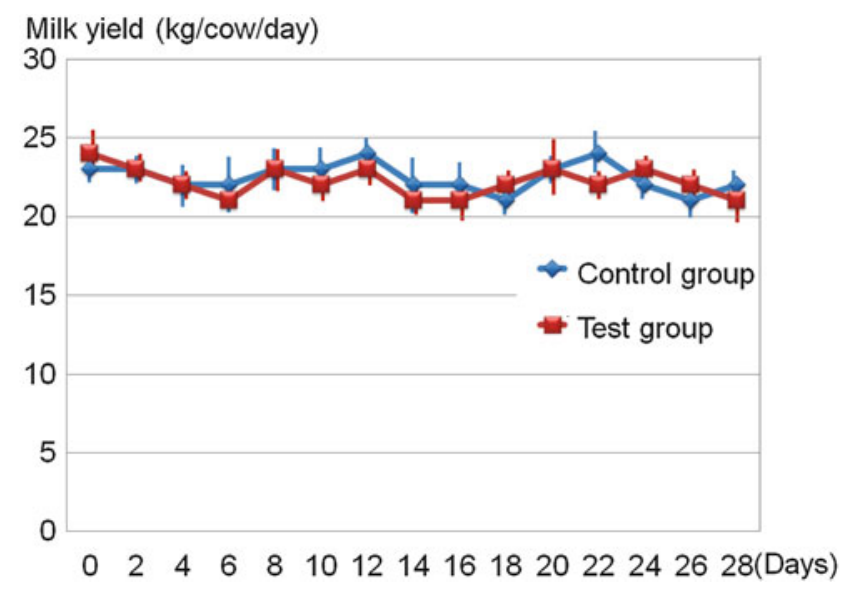

Fig. 9.1 Changes in milk yield (kg/cow/day). Milk yield was defined as the amount of twice morning and evening milking. Each point represents the mean \pm standard deviation

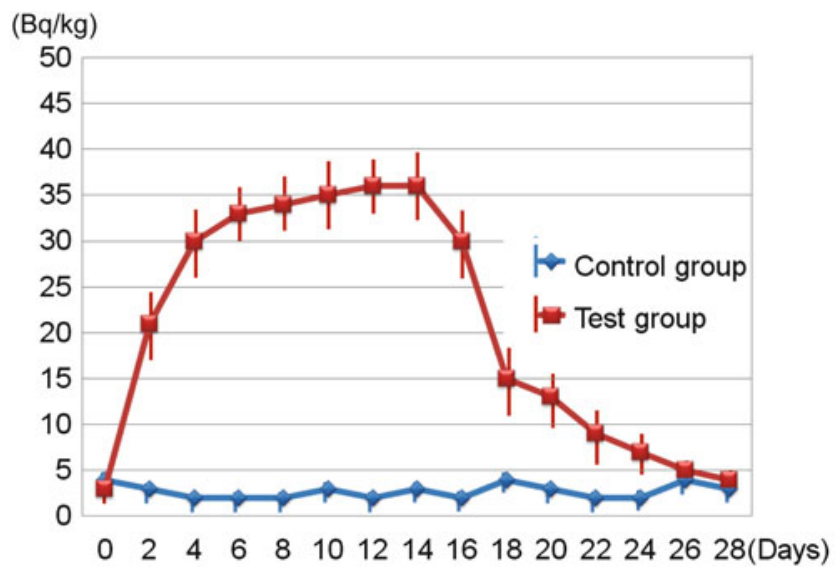

Fig. 9.2 Changes in concentrations of radiocesium in milk $(\mathrm{Bq} / \mathrm{kg})$. Each point represents the mean \pm standard deviation

blood biochemical parameters, urine biochemical parameters, or haematological parameters between these two groups (data not shown). The cows used were healthy.

(c) Changes in the concentrations of radiocesium in milk: as described above, cows in the test group were given $35 \mathrm{~kg} / 600 \mathrm{~kg}$ body weight/day of the mixture of haylage (not detectable level of ${ }^{131} \mathrm{I}$, and $1,260 \mathrm{~Bq} / \mathrm{kg}$ of radiocesium, ${ }^{134} \mathrm{Cs}$ and ${ }^{137} \mathrm{Cs}$ ) for 2 weeks, and then were given only $35 \mathrm{~kg} / 600 \mathrm{~kg}$ body weight/day of TMR for 2 weeks. As shown in Fig. 9.2, radioactivity concentrations of radiocesium in the milk rapidly increased to $30 \mathrm{~Bq} / \mathrm{kg}$ after 4 days from the start of feeding, and equilibrated to $36 \mathrm{~Bq} / \mathrm{kg}$ after 12 days. After stopping the feeding of forage with radiocesium, the concentration of radiocesium in the milk 
rapidly decreased at a rate of $2.05 \mathrm{~Bq} / \mathrm{kg} / \mathrm{day}$. Two weeks after stopping the feeding of forage, radioactivity concentrations of radiocesium were less than $5 \mathrm{~Bq} / \mathrm{kg}$, similar to background levels.

\subsection{Discussion}

The present findings showed that when cows (approximately $600 \mathrm{~kg}$ of body weight) were given feed with radiocesium $(12,600 \mathrm{~Bq} / 600 \mathrm{~kg}$ body weight/day of ${ }^{134} \mathrm{Cs}$ and ${ }^{137} \mathrm{Cs}$ ), $5.71 \%$ of ${ }^{134} \mathrm{Cs}$ and ${ }^{137} \mathrm{Cs}$ was secreted into the milk ( $720 \mathrm{~Bq} / 20 \mathrm{~kg}$ milk/day) after 10-14 days from the start of feeding. These radioactivity concentrations of radiocesium in the milk were lower than Japanese Government new standards $(50 \mathrm{~Bq} / \mathrm{kg}$ for radiocesium). After that, cows were given feed containing no radiocesium, and radioactivity concentrations of radiocesium in the milk rapidly decreased. Two weeks after stopping the feeding of forage with radiocesium, radioactivity concentrations decreased to background levels of less than $5 \mathrm{~Bq} / \mathrm{kg}$.

The transfer coefficient (Fm) for radiocesium transfer from cow feed to milk was calculated according to the following formula: Fm $($ day $/ \mathrm{L})=$ radiocesium concentration in milk $(\mathrm{Bq} / \mathrm{L}) /$ the amount of radiocesium intake in each cow (Bq/cow/day) (Sam et al. 1980; Johnson et al. 1988; Belli et al. 1993; Green and Woodman 2003; Robertson et al. 2003). In the present study, the radiocesium Fm value was 0.0029 (day/L) $(36 \mathrm{~Bq} / \mathrm{L} / 12,600 \mathrm{~Bq} / \mathrm{cow} /$ day $)$ at the highest point of radiocesium concentrations in the milk. When cows were given haylage that was contaminated with radiocesium for 1 month after the Chernobyl nuclear power plant accident, the radiocesium Fm value in the milk was approximately 0.005 day/L (Voigt et al. 1989; Vreman et al. 1989; Green et al. 1994; Fabbri et al. 1994; Gastberger et al. 2001; Howard et al. 2001; Beresford et al. 2000). In Japan, when dairy cows were raised under Japanese-style management and given contaminated haylage caused by the Fukushima Daiichi nuclear power plant accident, radiocesium Fm values were between 0.0027 and 0.0064 day/L (Beresford and Howard 2011, MAFF 2011; Manabe et al. 2011; Manabe 2012; Takahashi et al. 2012). Compiled results by the International Atomic Energy Agency (IAEA) showed radiocesium Fm values of approximately 0.005 day/L (IAEA 2005, 2009, 2010). In our preliminary experiment, when cows were given radiocesium contaminated haylage caused by the Fukushima Daiichi nuclear power plant accident for 5 days, the Fm value was 0.00096 day/L (Hashimoto et al. 2011). Thus, Fm values obtained in this study were lower that those of the Chernobyl experiment and IAEA report.

The two routes of radionuclide contamination of farm animals after the Fukushima Daiichi nuclear power plant accident were inhalation and ingestion of contaminated feed and water. Beresford and Howard (2011) reported that inhalation and water intake by animals were the most important routes in the early phase of the nuclear power plant accident. However, in the Animal Resource Science Center 
(140 km south-west from the Fukushima Daiichi nuclear power plant), the concentration of radionuclide contamination in the air was not at a detectable level 2 months after the accident. No radionuclide contamination in drinking water was detected. Intake via water is a small contributor. Hence, it is considered that the most important pathway to cows is the ingestion of radionuclide contaminated fodder in the present experiment.

The degree of absorption from the gastrointestinal tract is an important factor in determining radiocesium levels in animal tissues and milk. In the case of radiocesium, the source ingested is a major factor determining subsequent concentrations in tissues with the true absorption coefficient ranging from 0.10 to 0.80 (Howard et al. 2001). They showed that absorption levels of the radiocesium particle and soil binding radiocesium were lower than that of radiocesium incorporated within plants. In the present study, grass was grown for about 2 months after the Fukushima Daiichi nuclear power plant accident, harvested, and prepared for haylage. It has been suggested that the fermented grass forage used in the present study may have contained the radiocesium particle, which was fallout from the accident, soil binding radiocesium, and radiocesium incorporated within plants.

Once the cow has been removed from radiocesium contaminated forage, radiocesium concentrations in the milk rapidly decrease. The rate of loss of radioactive nuclides from milk is termed the biological half-life, which is defined as the time required for the radionuclide activity concentration in milk to be reduced by one half excluding physical decay. The rates of uptake and loss of radionuclides vary between animals and tissues. The biological half-life for radiocesium is associated with the metabolic turnover rate of caesium. Changes in radiocesium levels in milk after the Chernobyl nuclear power plant accident have been summarized by IAEA (2005). The rate of decline in radionuclide activity concentrations in milk of different species of dairy ruminants is rapid. The half-lives of radiocesium in milk are all in the range 0.5-3.5 days, values that are similar to our present result (approximately 2.0 days). The biological half-life of radiocesium in animals is an important factor influencing the effectiveness and practicalities of many countermeasures targeting animal derived foodstuffs, including decontamination using "Clean feeding" or Cs binders.

In the present study, we did not reveal changes in radioactive strontium $\left({ }^{90} \mathrm{Sr}\right)$, which accumulates in bones and plays a role as a carcinogenic factor, in milk. Further research on transfer kinetics and the coefficient of ${ }^{90} \mathrm{Sr}$ from forage contaminated by fallout from the Fukushima Daiichi nuclear power plant accident to the milk of cows is required. Moreover, the present findings involved the initial phase of the accident; therefore to remediate livestock management for radiocesium contamination under an "existing exposure situation" according to the ICRP (2009), further research is needed as follows: (1) improvements in pasture: to reduce radiocesium contamination in grassland, feasible and suitable surface improvements in grassland and radical improvements in meadow methods for Japanese farming practices have to be developed, (2) reductions in radiocesium intake: to prevent gut absorption by the application of radiocesium binding agents to animals, feasible and suitable agents have to be explored. The effectiveness and feasibility of candidate binding compounds, clay minerals, which adsorb caesium ions, such as bentonites, vermiculites, zeolites, added to fodder to reduce gut uptake of 
radiocesium by farm animals have been evaluated. The effectiveness and feasibility of the addition of hexacyanoferrate to feedstuffs have been also evaluated. The hexacyanoferrate compound, Prussian blue, is a radiocesium binder, which is added to the feed of farm animals to reduce radiocesium transfer to milk and other animal products by reducing absorption in the gut (IAEA 1997). Ammonium-hexacyanoferrate (AFCF), the commonly used form for remediation, was used extensively after the Chernobyl accident in Russia, Ukraine, and Belarus as well as in Western European countries, including Norway and Sweden, and was shown to be the most effective for animal use (Pearce 1994; Nisbet et al. 2010). Moreover, the acceptability of these strategies for Japanese farmers also needs to be investigated, and (3) Collateral safety of animal products: to produce milk without disrupting normal farming practices, "Clean feeding" management has been considered feasible and suitable. Farm animals are provided uncontaminated feed or forage with acceptable levels of radiocesium. To prevent radiocesium contamination of animal products by ensuring that feedstuffs that are too highly contaminated are not ingested by farm animals, a registration system to identify individual farm animals has to be developed.

\subsection{Conclusion}

Radiocesium contamination of animal products is an important potential route of internal exposure in the human food-chain after the Fukushima Daiichi nuclear power plant accident. Most farm animals are kept in closed barns in Japan. Housing farm animals reduced initial radioactive nuclide contamination of animal products in the early phase of the Fukushima Daiichi nuclear power plant accident. Moreover, in Japan, pigs and chickens were given imported feed that contained no radioactive nuclide contamination caused by the accident, a livestock management system called "Clean feeding". However, adequate amounts of grass feed, at least $30 \%$, are essential for rearing cattle, and uncontaminated feed and/or forage containing acceptable amounts of radiocesium are needed. In conclusion, the present findings revealed that when cows received radiocesium contamination of less than $300 \mathrm{~Bq} /$ $\mathrm{kg}$, they produced milk contaminated with less than $50 \mathrm{~Bq} / \mathrm{kg}$ radiocesium.

Open Access This article is distributed under the terms of the Creative Commons Attribution Noncommercial License which permits any noncommercial use, distribution, and reproduction in any medium, provided the original author(s) and source are credited.

\section{References}

Belli M, Sansone U, Piasentier E, Capra E, Drigo A, Menegon S (1993) ${ }^{137}$ Cs transfer coefficients from fodder to cow milk. J Environ Radioact 21:1-8

Beresford NA, Howard BJ (2011) An overview of the transfer of radionuclides to farm animals and potential countermeasures of relevance to Fukushima releases. Integer Environ Assess Manage $7: 382-384$ 
Beresford NA, Gashchak S, Lasarev N, Arkhipov A, Chyomy Y, Astasheva N, Arkhipov N, Mayes RW, Howard BJ, Baglay G, Logovina L, Burov N (2000) The transfer of ${ }^{137} \mathrm{Cs}$ and ${ }^{90} \mathrm{Sr}$ to dairy cattle fed fresh herbage collected $3.5 \mathrm{~km}$ from the Chernobyl nuclear power plant. J Environ Radioact 47:157-170

Fabbri S, Piva G, Sogni R, Fusconi G, Lusardi E, Borasi G (1994) Transfer kinetics and coefficients of ${ }^{90} \mathrm{Sr},{ }^{134} \mathrm{Cs}$ and ${ }^{137} \mathrm{Cs}$ from forage contaminated by Chernobyl fallout to milk of cows. Health Phys 66:375-378

Gastberger M, Steinhausler F, Gerzabeck M, Hubmer A (2001) Fallout strontium and caesium transfer from vegetation to cow milk at two lowland and two Alpine pastures. J Environ Radioact S4:167-273

Green N, Woodman RFM (2003) Recommended transfer factors from feed to animal products. National Radiological Protection Board (NRPB) report, Oxon, April 2003, pp 1-57

Green N, Wilkins BT, Hammond DJ (1994) The transfer of ${ }^{137} \mathrm{Cs}$ and ${ }^{90} \mathrm{Sr}$ along the soil-pasture-cows' milk pathway in an area of land reclaimed from the sea. J Environ Radioact 13:151-170

Hashimoto K, Tanoi K, Sakurai K, Hashimoto T, Nogawa N, Higaki S, Kosaka N, Takahashi T, Emoto Y, Onoyama I, Li JY, Manabe N, Nakanishi T (2011) The radioactivity measurement of milk from the cow supplied with pasture grown in Ibaraki-prefecture, after the Fukushima nuclear power plant accident. Radioisotopes 60:335-338

Howard BJ, Beresford NA, Voigt G (2001) Countermeasures for animal products: a review of effectiveness and potential usefulness after an accident. J Environ Radioact 56:115-137

International Atomic Energy Agency (IAEA) (1997) The use of Prussian blue to reduce radiocaesium contamination of milk and meat produced on territories affected by the Chernobyl accident. In: IAEA=TECDOC-926, IAAEA, Vienna

International Atomic Energy Agency (IAEA) (2005) Environmental consequences of the Chernobyl accident and their remediation: twenty years of experience report of the UN Chernobyl forum expert group "Environment" (EGE). IAEA, Vienna

International Atomic Energy Agency (IAEA) (2009) Quantification of radionuclide transfer in terrestrial and freshwater environments for radiological assessments. In: IAEA-TECDOC-1616, IAEA, Vienna

International Atomic Energy Agency (IAEA) (2010) Handbook of parameter values for the prediction of radionuclide transfer in terrestrial and freshwater environments. In: IAEA-TRS 472, IAEA, Vienna

International Commission on Radiological Protection (ICRP) (2009) Application of the commission's recommendations to the protection of people living in long-term accident or a radiation emergency. ICRP publication 111. In: Annals of the ICRP No. 39, Elsevier, Amsterdam

Johnson JE, Ward GM, Ennis ME Jr, Boamah KN (1988) Transfer coefficients of selected radionuclides to animal products: 1 . Comparison of milk and meat from dairy cows and goats. Health Phys S4:161-166

Manabe N (2012) Metabolism of radioactive cesium in dairy cows. Chem Biol 50:668-670

Manabe N, Li JY, Takahashi T, Endo M, Emoto Y, Tanoi K, Sakurai K, Nakanishi T (2011) Transition to the milk of radioactive materials in feed for dairy cattle and future pollution control. Dairy Japan 12:25-27

Ministry of Agriculture, Forestry and Fisheries of Japan (MAFF) (2011) Setting the tolerance improvement materials and feed fertilizer including radioactive cesium: 2. allowable radioactive cesium in the feed (in Japanese)

Nisbet AF, Brown J, Howard BJ, Beresford NA, Ollagnon H, Turcanu C, Camps J, Andersson K, Rantavaara A, Lkaheimonen T, Duranova T, Oughton D, Kirchner G, Papachristodoulou C, Ioannides K, Kwakman P (2010) Decision aiding handbooks for managing contaminated food production systems, drinking water and inhabited areas in Europe. Radioprotection 45:S23-S37

Pearce J (1994) Studies on any toxicological effects of Prussian blue compounds in mammals: a review. Food Chem Toxicol 32:577-582 
Robertson DE, Cataldo DA, Napier BA (2003) Literature review and assessment of plant and animal transfer factors used in performance assessment modeling. United States Nuclear Reguratory Commission (USNRC), NUREG-CR-6825

Sam D, Williams WF, Rockmann DD, AIlen JT (1980) Transfer coefficients of radionuclides secreted in milk of dairy cows. J Dairy Sci 63:1447-1450

Takahashi T, Emoto Y, Endo M, Onoyama I, Tomimatsu S, Ikeda M, Li JY, Tanoi K, Nakanishi T, Manabe N (2012) Changes in radionuclide levels in milk from the cow supplied with pasture grown in Ibaraki Prefecture, after the accident in Fukushima Daiichi nuclear power plant. Radioisotopes 61:551-554

Voigt G, Muller HP, Prohl GP, Paretzke HG, Propstmeier G, Rohrmoser GH, Hofmann P (1989) Experimental determination of transfer coefficients of ${ }^{137} \mathrm{Cs}$ and ${ }^{131} \mathrm{I}$ from fodder into milk of cows and sheep after the Chernobyl accident. Health Phys 57:967-973

Vreman K, van der Struij TDB, van den Hoek J, Berende PLM, Goedhart PW (1989) Transfer of ${ }^{137} \mathrm{Cs}$ from grass and wilted grass silage to milk of dairy cows. Sci Total Environ 85:139-147 